\title{
Preaching, Prosperity, and Product Sales: A Profile of On-Demand Digital Audio Offerings of Christian Renewalist Ministries
}

\author{
Douglas J. Swanson \\ Journalism Department \\ California State Polytechnic University
}

In the United States alone, millions of listeners tune in to Internet-based audioon-demand (commonly known as podcast programming). Religious programming is among the fastest-growing podcast areas. Since studies show that evangelicals are known to be quick to adopt new technology, this research involved a content analysis of 67 podcast episodes produced by five well-known renewalist evangelical ministries. The study found most podcasts were not original in content and were not consistently available for listeners to download. Also, the podcasts had poorer production values than would be expected from broadcast programming. A frame analysis identified ministries' justification of religious messages, listener responses sought, and rewards promised to listeners. More research is needed to answer questions about the impact on listeners and compare the content of renewalist program offerings to other Christian podcasts.

\section{INTRODUCTION}

Podcasting, the creation and use of digital on-demand audio, exploded into popular culture in fall 2001 with the introduction of Apple's iPod player. In just a few years, iPods, as well as a collection of imitators that also play mp3 audio, have gone from novelty items to must-have technology for millions.

Despite the popularity of digital audio players and content, "almost nothing is known about listeners, their habits, or podcast demand" (Brown, 2006, Abstract). 
The research literature is just beginning to pay attention to podcasting, with recognition that podcasts are easy to create (Humphries, 2004), can help market products (Bannan, 2006), deliver news (Potter, 2006), and aid learning (Richardson, 2006; Herringron, 2005).

Although we know podcasts are increasingly used by religious groups (Rodgers, 2006; Ralli, 2005), the literature affirms little about podcast content. The present

study, although small in scope, adds to our knowledge by focusing on digital audio programming created to support and encourage listeners in religious movements. The study specifically focuses on renewalist evangelical Christian ministries.

Renewalism is a growing segment of evangelical Christianity that holds to the belief that God actively intervenes on behalf of faithful believers to heal and make them rich (Olsen, 2006). In recent years, the number of people identifying with renewalist Christian ideology has increased dramatically, as has the number of ministries that have a worldwide electronic outreach. One estimate shows renewalism is embraced by more than a quarter of the world's two billion Christians (Biema \& Chu, 2006). Renewalism is characterized by "folksy" preachers, multiple merchandising appeals, and sophisticated creation and dissemination of media that espouse divinely authorized health and wealth.

Over the years, the popular perception of the conservative evangelist was "one of smarmy huckster: a used car salesman with a hair stylist" (Howley, 2001, p. 26). Today's renewalist evangelicals are trying to change that image in several ways, including using new media. Studies have shown that evangelicals are among the most willing Christians to embrace new communication technologies (Hoover, Clark, \& Rainie, 2004). Investigation is warranted into how leading renewalist ministries use podcasting to communicate their "health and wealth" message to listeners.

This study employed a systematic content analysis of podcast "eposides" to reach conclusions about what podcast listeners could expect to encounter in renewalist programming. Specifically, this includes the availability of podcasts, the rhetorical content of programming, and the level of originality of that content. The author employed media frame analysis to isolate claims made to faithful listeners through podcasts, as well as the kinds of responses asked of listeners and the rewards promised to listeners by ministries.

This research cannot answer all relevant questions about religious use of on-demand media or address the use of media among all Christian believers. It can, however, foster a clearer understanding of how certain Christian ministries within a prominent, growing doctrinal area use podcasting to communicate with listeners today.

\section{LITERATURE REVIEW}

People use the Internet to seek information, meet others, pass time, be entertained, and add convenience to their lives (Papacharissi \& Rubin, 2000). While 
the technology to transmit audio content over the Internet is not new, the explosion of on-demand audio activity is a recent phenomenon that can be traced to Apple's introduction of the iPod digital audio player in fall 2001. Though the iPod is not the only device capable of playing mp3 format audio, more than 100 million iPods have been sold (100 million . . ., 2007). By 2006, more than $70 \%$ of digital audio players sold were iPods (Marsal, 2006).

As iPod players flew off store shelves all over the world, a dramatic escalation in the creation of podcast audio content took place. There were only a few thousand podcasts available on the Internet in January 2005. By June 2005, the number had grown to more than 25,000 (Bullis, 2005). Some recent blog conversations have suggested there may be more than 300 million podcasts, although these claims cannot be verified. It is equally difficult to authoritatively gauge how many listeners are downloading and using podcasts. Estimates have varied from 5 million (Huntsberger \& Stavitsky, 2007), to 12 million (Bannan, 2006), to $8 \%$ of the American adult population - which would be approximately 17 million people (Klaassen, 2006). One estimate suggests 45 million people may be listening to podcasts by the end of this decade (Potter, 2006).

A podcast facilitates active information seeking (Inglis, Ling, \& Jootsen, 2002) because it puts listeners in control of the technology (Johnson \& Grayden, 2006). Podcast creators can heighten the personalization of the medium through a "microtarget" approach (Snodgrass, 2007, para. 2), meaning audio creators can make connections with listeners interested in highly specific ideas, entertainment, or products. Allowing the listener to be in control of the communication while focusing in on the specific needs and wants of that person creates the kind of marketing relationship organizations want today one in which audiences and publics are aware, active, and assertive as consumers to get the information they need about relevant issues of life (see Lesig, 2001).

Clearly, this kind of relationship is the goal of many modern religious organizations. This is especially true of Pentecostal and evangelical Christian ministries that are often classified together as renewalists. Ministries such as those of Kenneth Copeland, Creflo Dollar, and Joel Osteen use modern marketing techniques to reach as many people as possible with "an upbeat message [that is] intertwined with a religious one" (Symonds, Grow, \& Cady, 2005, para. 6). These ministries and others like them have an active online presence that allows them to connect on as many levels as possible with active information seekers (Blake, 2007). Podcasting is one of those levels.

Podcasting seems to be an ideal way to reach Christian listeners because it is less expensive to produce and disseminate than traditional radio programming. It offers "religion on the fly" for busy people (Ralli, 2005, p. 15) and can make religious ideas seem less socially divisive (Karkabi, 2006). The personalization potential for the medium would seem to allow podcasts to integrate well with 
"the entrepreneurial drive" that Ralli (2005, p. 15) and others have observed among Christian evangelicals.

Although podcasting of religious content is gaining in popularity (Kloer, 2006; Rodgers, 2006), the exact amount of Christian podcast content is unknown. In 2005, Kennedy cited one popular Christian podcast page that had attracted one million regular users and estimated that religious podcasting was the fastest-growing genre in the podcast realm (2005). Another 2005 estimate claimed religious podcasts comprised $5 \%$ of all published listings (Bullis, 2005).

\section{RESEARCH DESIGN}

This research required an objective means of locating Christian podcasts, listening to and objectively examining them, and then making comparisons about technical aspects, creative content, and direct, purposive communication with listeners to engender particular responses. The content analysis method was chosen because it allows for measurement of communication content in a manner that is objective and reasonably quantitative. Content analysis allows for a "systematic examination of materials that are more typically evaluated on an impressionistic basis" (Babbie, 1990, p. 30). It allows a researcher to "select some aspects of a perceived reality and make them more salient in a communicative text" in order to define and interpret communication content (Entman, 1993, p. 52).

Frame analysis was used as an organizing device to make conclusions about qualitative issues that would arise during content analysis (see, e.g., Cutbirth, 1983). Frame analysis allowed the researcher to isolate issues that podcasts

portrayed as salient for listeners' consideration from those that were not (see Tankard, 1997).

\section{RESEARCH QUESTIONS}

Five research questions were posed in regard to the content of digital audio podcasts produced by leading renewalist Christian ministries and made available through links on the World Wide Web:

RQ1: How accessible was podcast content?

RQ2: How were podcasts presented and structured?

RQ3: What can be said about subject content of podcasts?

RQ4: What religious claims were made within podcasts?

RQ5: How were listeners asked to respond to podcasts? 


\section{METHODS}

This section details the methods used to identify renewalist ministries from which podcasts would be gathered for analysis. It then explains the time frame for the study and the system through which ministries' podcasts were retrieved.

The author began with a list of more than two-dozen evangelists and ministries identified in recent comprehensive articles on prosperity theology (Biema \& Chu, 2006; Symonds, Grow, \& Cady, 2005) and in a "televangelist report card" (Winzenburg, 2001). An extensive online search was conducted using relevant search terms entered into the Google search engine to locate organizations not named in the three articles.

Not surprisingly, the Google search resulted in links to hundreds of religious organizations that fell within the renewalist classification. Therefore, it was decided to limit the potential population for study to renewalist ministries that had a single prominent leader, addressed a worldwide audience, used a Web site that disseminated free audio/visual programming, and was not affiliated with any specific religious denomination.

Five renewalist ministries met all these criteria. During the study period of June 1-30, 2007, the author made downloads of all podcast audio content made available by these ministries. Podcasts were retrieved by subscription through the Apple iTunes Web site; all podcasts made available from the ministries were retrieved automatically. A total of 67 podcasts were downloaded. The author listened to each podcast and conducted a content analysis for each during the study period. Analysis of all programming was completed by June 30. Podcasts released on iTunes after the end of the study period but dated within the study period were not included in the study.

\section{RESULTS}

This section addresses each of the research questions individually. It includes an explanation of findings related to podcast accessibility. It explains the key observed similarities and differences of the audio content of the 67 podcast episodes, including the desired responses that podcasts sought from listeners.

RQ1: How accessible was podcast content?

Podcast content is easy for listeners to access, provided listeners have the appropriate computer hardware and software at their disposal. Podcast content is not easy for listeners to access if the content is not made available by the program hosts or is labeled in a confusing or incorrect way by the program hosts.

At the outset of this study, 13 renewalist ministries met some of the criteria for inclusion. However, eight ministries (61\%) were subsequently disqualified 
because their podcast programming was not available as promised on the ministries' Web pages. Typically this was due to inoperable hyperlinks or other technical issues. See Table 1 for a listing of the disqualified ministries, their Web site URLs, their ministerial slogans, and explanation of issues related to podcast content access.

Five renewalist Christian ministries met all study criteria as explained above and had audio on demand programming that was accessible during the study period. These ministries are listed in Table 2.

\section{RQ2: How were podcasts presented and structured?}

Generally, ministries did not make new podcasts available with regularity and consistency throughout the study period. When ministries did make podcasts available, they tended to be consistent in format with previously released episodes. Content was mostly sermon-based and evangelical, meaning the programming seemed to target already committed listeners rather than those new to Christianity.

Ministries released as few as two (Houston) and as many as 24 podcast episodes (Copeland) during the 30 days of the study period. Ministries would go for as many as nine days without posting new programming, and then would release as many as seven episodes simultaneously (Dollar). One Kenneth Copeland episode dated June 24 was analyzed and later excluded from the study population because its content was identical to another episode dated June 27. Two Joel Osteen podcasts labeled with the same release date had different content.

None of the 67 podcasts was identified as original audio programming. Forty-eight of the episodes $(72 \%)$ included the sound of a live audience, along with comment from the announcer or preacher indicating the program was an audio track from a television broadcast. Comment included announcer requests to call "the phone number on your screen" or donate "the amount shown or more" (Dollar), program closings in which the preacher said "thank you for tuning in" (Osteen), and even a lengthy introduction of staff who work "behind the camera" (Copeland, June 19). It was unclear whether the remaining 19 episodes $(28 \%)$ in which audience response was not heard on audio were originally aired on television. Because none was identified as content created exclusively for podcast, it was impossible to know for sure.

Sixty-five of the episodes $(93 \%)$ included an announcer's introduction and preview of contents. Twenty-three of the episodes (34\%) offered a recap of a previous episode. Merchandising communication was present in 61 of the episodes (97\%) and included highly persuasive appeals to purchase products or services.

Four of the five ministries' episodes were approximately the same length consistently. The episodes ranged from Joyce Meyer's average of 14:31 to Joel Osteen's average 31:55. Although Brian Houston had the lengthiest single podcast (41 minutes on June 13), it was one of only two episodes released by that ministry during the study period and, therefore, is probably not effectively compared with the others. 
TABLE 1

Ministries Lacking Accessible On-Demand Audio During the Study Period

Ministry

Audio-Only Programming Identified and Available?

Juanita Bynum

Women on the Frontline

http://www.juanitabynum.com/

"More than a ministry."

Paul Crouch

Trinity Broadcasting Network

http://www.tbn.org/

"Touching billions now."

Marilyn Hickey

Marilyn Hickey Ministries

http://www.mhmin.org/

"Covering the earth with the word."

Benny Hinn

Benny Hinn Ministries

http://www.bennyhinn.org/

"Winning the lost at any cost."

T.D. Jakes

The Potter's House

http://www.thepottershouse.org

"Reaching the lost and the broken."

Rod Parsley

Rod Parsley Ministries

http://www.rodparsley.com/

"Back to Bible basics."

Oral Roberts

Oral Roberts Ministries

http://portal1.oru.edu/pls/portal/

ORMCCMGR.DYN_ORM_HOME_2.sho

w?p_arg_names $=p \_i d \& p \_a r g \_v a l u e s=1082$

"Jesus' resurrection power."

Robert Tilton

Robert Tilton Success $N$ Life Ministries

http://www.roberttilton.tv/

"Reaching the unreached: Bringing hope and destiny to a hurting world."

No audio programming linked to Web site.

No podcast subscription available on iTunes.

No audio programming linked to Web site.

(On-demand video was available on Web site.)

No podcast subscription available on iTunes.

No new content listed during study period.

Older on-demand audio was linked to Web site, but these links were inoperable.

No subscription available on iTunes.

On-demand audio linked on Web site

through paid subscription only.

No subscription available on iTunes.

No audio programming linked to Web site.

No podcast subscription available on iTunes. *

No audio programming linked to Web site.

No podcast subscription available on iTunes.

Only one undated sermon offered on Web site; the link was inoperable.

No subscription available on iTunes.

No audio programming linked to Web site.

(On-demand video was available on Web site.)

No podcast subscription available on iTunes.

*Timiraos (2006) claimed T.D. Jakes was developing a \$14.95 per month "pay to play" podcast and would hand out free iPods to promote the service. But no evidence of the existence of this service could be found on Jakes' ministry Web page or on iTunes. 


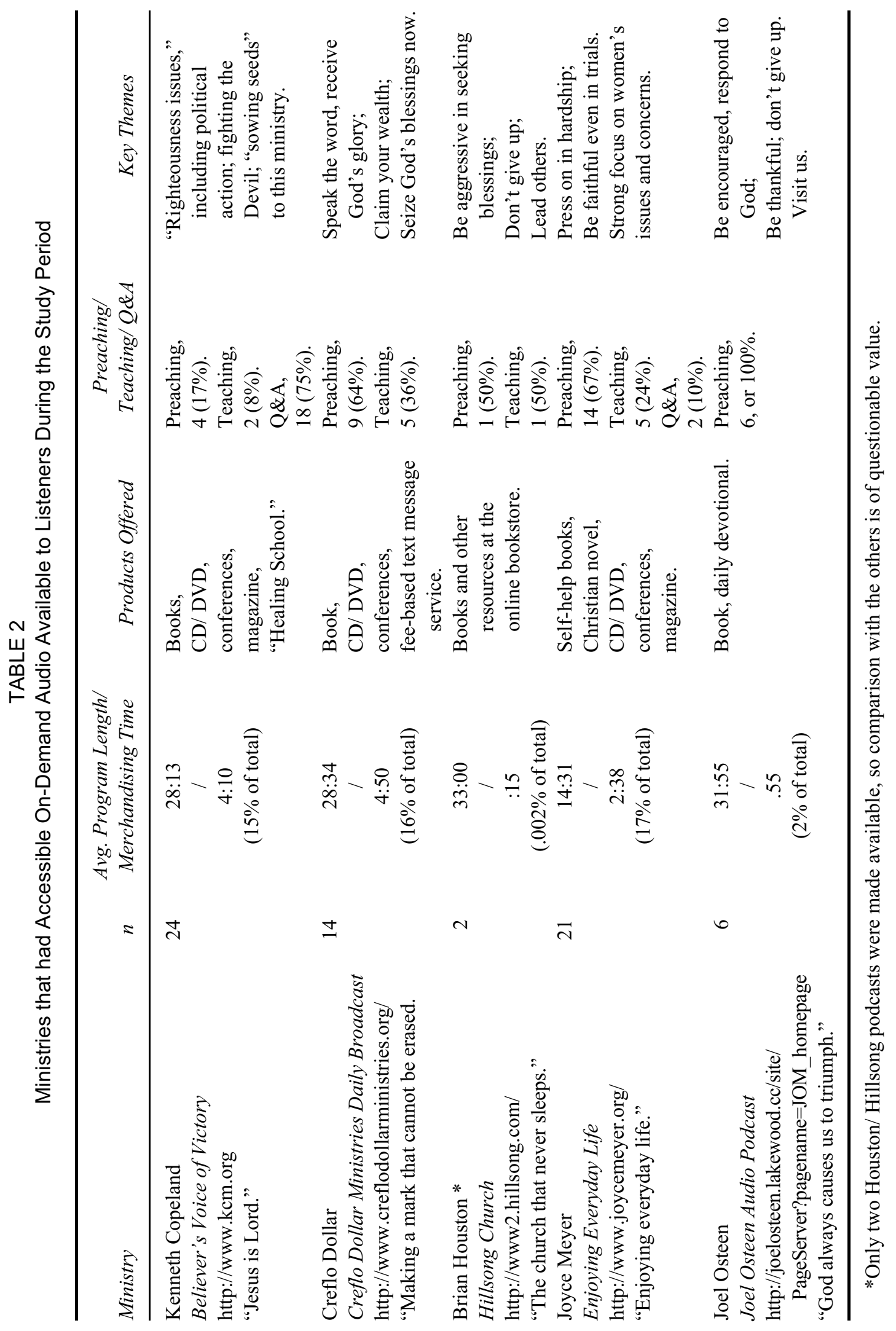


Production values were of lesser quality than a listener might expect, given that all of these ministries have the personnel and resources to support worldwide broadcast operations. It was obvious that some episodes joined a sermon at the midway point (Copeland). Some sermons came to an abrupt end in mid-sentence (Dollar, Meyer). Others used only the middle section of a sermon, without the introduction and conclusion (Dollar). Some podcast episodes had superfluous sermon content or verbal gaffes that were not edited out. These obvious content irregularities seemed odd, given that the digital audio software used for producing podcasts makes high quality editing easy for even a novice audiophile.

Each of the 67 podcasts took the form of a church sermon, conference lecture, or question/answer (Q\&A) session with an invited guest. All were persuasive in nature. None was simply informative in nature and all offered only rhetorical content. There were, for example, no programs comprised only of instrumental music or choir performances, although most programs opened with some sort of musical interlude.

Overall, 49 of the podcast episodes $(73 \%)$ were part of a series on a particular topic. On occasion, the subject content became redundant. One example of this would be a two-week John Copeland Q\&A series on "How to love someone you don't like" that covered the same thematic points in several of the 28-minute episodes. On the other hand, some podcast episodes did not offer enough explanatory information for listeners. For example, a June 11 Joel Osteen podcast featured a guest preacher who was never identified by name. A June 18 Joel Osteen podcast featured a sermon by Lisa Comes, who was identified by name but not identified as Osteen's sister.

Table 2 contains a listing of the five qualifying ministries, their Web site URLs, and their ministerial slogans. It also includes a display of key issues related to podcast content.

RQ3: What can be said about subject content of podcasts?

The vast majority of podcasts listened to by the author and analyzed for this study were found to be evangelistic in nature and declarative. This means most podcasts featured a minister persuasively offering listeners absolute truths about "health and wealth" doctrine. Preaching almost always segued directly into a request for listeners to make a donation or purchase a product.

Of the 67 podcast episodes analyzed for this research, $66(99 \%)$ were found to be evangelistic in nature. This means they presented truths through narrative without specifically recognizing in the audio content that the listener might be hesitant or doubtful. Only one Kenneth Copeland episode (June 3) directly addressed nonbelievers.

Podcast episode content that featured the preacher speaking persuasively in a declarative fashion was coded as preaching. A total of 34 episodes (51\%) met this standard. Episode content in which the preacher offered persuasive rhetorical content through some level of conversational interaction with a present audience 
was coded as teaching. A total of 13 episodes met this standard (19\%). Episode content in which the program host was speaking with an invited guest was coded as Q\&A (question and answer). A total of 20 episodes met this standard (30\%).

In most cases, the content of Q\&A format episodes was declarative, not inquisitive. In other words, the host used the guest expert for amplification of the ministry's claims, not for inquiry about issues of faith. Ninety percent of the total Q\&A content was found within episodes of the Kenneth Copeland Believer's Voice of Victory program and consisted of declarative attacks against abortion, homosexuality, liberal judges, and public schools.

Most podcast episodes included a call for listeners to give money. The request to give was voiced by a preacher approximately $24 \%$ of the time, but requests to donate were communicated in almost every program by an unidentified announcer. Requests were typically phrased as that of "sowing a seed." Kenneth Copeland defended the practice (June 8), saying that Christian preaching "is not scriptural until you give people an opportunity to sow." Copeland told his audience (June 18) that audience members "can't be blessed until they give" (June 18). Creflo Dollar, who made the most number of personal requests (in 9 out of 14 episodes, or 64\%), told listeners (June 15) "giving is a sign of your obedience to God."

Podcast listeners were asked to purchase an immense variety of products and services. Amounts of time spent in product sales varied (see Table 2). Joyce Meyer devoted the most time to this effort, with an average of 2:38, or approximately $17 \%$ of total program time. Totals shown in Table 2 are approximate because preaching typically segued seamlessly into merchandising communication. Usually a musical bridge joined the two, to transition the program from preaching to selling.

A "salvation package" (Copeland), a paid subscription cell phone daily devotional text messaging service (Dollar), nonfiction books, a novel (Meyer), magazines (Osteen), CD and DVD offerings, and multiple opportunities for travel and conference attendance were among what was peddled before, during, and at the end of podcast episodes.

RQ4: What religious claims were made within podcasts?

There was a strong general consistency of religious claims made by all podcasts. At the same time, each ministry's podcast couched claims within a unique theme or rhetorical approach consistent with the personality of the preacher.

All programming affirmed for listeners that the Bible is the revealed word of God, and that salvation comes through a personal "born again" relationship with Jesus Christ. Podcasts supported key renewalist themes, primarily the idea that God wants his people to be wealthy and in good health. Podcasts affirmed either directly or implicitly for listeners that the Devil or Satan is a real, threatening being. A key support for claims made by Christians is the Bible. Specific Bible references were used by preachers an average of 3.62 times per episode. 
Each preacher drew heavily from personal experience to support claims made to listeners within the audio programs. Preachers' personal examples were cited as support for claims made in 59 episodes (88\%); hypothetical examples were cited as support in 39 episodes (59\%). Personal examples of people other than the preacher were cited as support for claims made in 34 of all episodes (51\%).

Overall, analysis showed preachers offered five major rational justifications to listeners for claims made within podcast episodes. Those rational justifications are shown in Table 3.

Kenneth Copeland was the most politically focused of the program hosts. He spoke persuasively of "absolute rights and wrongs" (June 1) in regard to political actions of Christians. Typically, Copeland used his podcasts' Q\&A format to present his views and have them echoed by a compliant guest. In various episodes, Copeland spoke to listeners about "ungodly state schools" (June 5) and "knucklehead judges" (June 7). He talked of public school teachers as "dummies" (June 7), claimed the ACLU "is used by Satan to oppress people" (June 14), and proposed aggressive conversion of Muslims to Christianity (June 21).

Creflo Dollar used frequent slang references that suggest a targeting of urban minority group members. He often told stories of street corner conversations and other activities that suggested a knowledge of and concern for urban life. The Dollar podcasts encouraged listeners "to say I'm prosperous, I'm wealthy, and I'm rich" (June 18). Dollar often referred to his own material wealth and, on three occasions, spoke about how he enjoys his jet airplane.

Joyce Meyer almost exclusively addressed women's issues. Her themes dealt consistently with homemaker issues such as cooking, cleaning, shopping and other domestic tasks. She spoke often of her joy of shopping and struggle with dieting. Meyer suffered sexual abuse as a child, had an early unhappy marriage,

TABLE 3

Explicit or Implied Justification Offered to Listeners

\begin{tabular}{lcccccc}
\hline & $\begin{array}{c}\text { Copeland } \\
(n=24)\end{array}$ & $\begin{array}{c}\text { Dollar } \\
(n=14)\end{array}$ & $\begin{array}{c}\text { Houston } \\
(n=2)\end{array}$ & $\begin{array}{c}\text { Meyer } \\
(n=21)\end{array}$ & $\begin{array}{c}\text { Osteen } \\
(n=6)\end{array}$ & $\begin{array}{c}\text { All } \\
(n=67)\end{array}$ \\
\hline $\begin{array}{l}\text { Truth revealed by God } \\
\text { Word of God }\end{array}$ & 0.50 & 0.43 & 0.50 & 0.81 & 0.83 & 0.61 \\
$\begin{array}{l}\text { Truth revealed by } \\
\text { preacher }\end{array}$ & 0.38 & 0.79 & 0.00 & 0.29 & 0.17 & 0.32 \\
$\begin{array}{l}\text { To fight the Devil } \\
\text { Political necessity }\end{array}$ & 0.50 & 0.00 & 0.50 & 0.05 & 0.17 & 0.24 \\
$\quad$ dictates it & 0.21 & 0.14 & 0.00 & 0.10 & 0.33 & 0.16 \\
\hline
\end{tabular}

(Multiple justifications were observed within individual episodes).

Tables represent rate of occurrence of each rational justification of claims made within podcast episodes. 
and dealt with professional setbacks as she tried to build a preaching career in a male-dominated profession. She used these experiences to encourage women to persevere through difficult times and "enjoy everyday life" by finding the blessings God has in store for them. Meyer told listeners (June 11) she is a straight-talking Missourian who has no patience for complainers and feels that those who do "just need to get a life!"

Joel Osteen, like the other preachers described here, was welcoming in his speaking style. His Texas drawl seemed gentler than Copeland's and his folksy delivery was perceived to be less aggressive. Osteen's podcasts offered the most positive affirmations. Osteen made no effort to problem-solve, and never presented listeners with unpleasant subjects such as war, politics, sin, sickness or death. Everything was a vision of sweetness and light, sprinkled with messages of "can do power" because "there is nothing in your future you cannot accomplish" (June 6). Osteen gave scant audio time to issues of merchandising and fundraising, and never personally asked for a donation in the six episodes released in the study period.

Osteen spoke in what's called "preacher-speak," using a sing-song tone and over-emphasizing particular words and phrases for emphasis that is unnatural as compared with the cadence used in conversation. The problem with this is that people who are not committed believers "see it as performance, not as heartfelt communication" (Church for Men . ., 2005, para. 7). The podcast is a personal medium of direct communication - from speaker to listener. In this medium, Osteen's delivery could be perceived by some as disingenuous and overpower the religious claims he was trying to make. Some podcast listeners might perceive less sincerity due to the fact that Osteen began every podcast by saying "thank you for watching" or a "thank you for tuning in." (It is awkward enough to hear this welcome via audio podcast, but it is even more odd when one considers that Osteen was speaking, at the time of recording, to a present audience in a church service.)

RQ5: How were listeners asked to respond to podcasts?

Podcast hosts sought eleven different types of responses from listeners. The most common desired responses were for listeners to strengthen their faith - and change their behavior to be more Christian-like. Among the responses least asked for directly or through implication were for listeners to read their Bible, go to church or be healed. Listeners were continually asked to give money and purchase products. A summary of the responses sought from listeners is shown in Table 4.

Podcasts promised listeners 11 types of rewards, either through direct promise of the preacher, or through implication that the rewards will follow as a result of proper motive and action. The most common rewards promised to listeners were of lifestyle improvement and emotional satisfaction and peace of mind. The least common rewards were of political rights, acceptance or related satisfaction, and 
TABLE 4

Explicit or Implied Desired Responses from Listeners

\begin{tabular}{|c|c|c|c|c|c|c|}
\hline & $\begin{array}{c}\text { Copeland } \\
(n=24)\end{array}$ & $\begin{array}{l}\text { Dollar } \\
(n=14)\end{array}$ & $\begin{array}{c}\text { Houston } \\
(n=2)\end{array}$ & $\begin{array}{l}\text { Meyer } \\
(n=21)\end{array}$ & $\begin{array}{l}\text { Osteen } \\
(n=6)\end{array}$ & $\begin{array}{c}\text { All } \\
(n=67)\end{array}$ \\
\hline $\begin{array}{l}\text { Be evangelized; strengthen your } \\
\text { faith }\end{array}$ & 0.58 & 0.71 & 0.50 & 0.95 & 1.00 & 0.75 \\
\hline $\begin{array}{l}\text { Be more Christianly; change your } \\
\text { habits }\end{array}$ & 0.21 & 0.79 & 0.50 & 0.76 & 0.50 & 0.55 \\
\hline Help other people & 0.13 & 0.00 & 1.00 & 0.00 & 0.17 & 0.26 \\
\hline $\begin{array}{l}\text { Donate to this ministry (preacher } \\
\text { request) }\end{array}$ & 0.25 & 0.64 & 0.00 & 0.05 & 0.00 & 0.24 \\
\hline Be more thankful to God & 0.00 & 0.00 & 0.00 & 0.10 & 0.50 & 0.12 \\
\hline Resist the Devil & 0.21 & 0.07 & 0.00 & 0.24 & 0.00 & 0.10 \\
\hline Come to Jesus; dedicate your life & 0.21 & 0.07 & 0.00 & 0.00 & 0.17 & 0.09 \\
\hline Attend our church or conference & 0.13 & 0.00 & 0.00 & 0.00 & 0.33 & 0.09 \\
\hline Read or study the scripture & 0.04 & 0.21 & 0.00 & 0.10 & 0.00 & 0.07 \\
\hline Go to church & 0.13 & 0.00 & 0.00 & 0.00 & 0.17 & 0.06 \\
\hline Be healed & 0.25 & 0.00 & 0.00 & 0.00 & 0.00 & 0.05 \\
\hline
\end{tabular}

(Multiple responses were requested within individual episodes).

Tables represent rate of occurrence of specific responses requested of podcast listeners.

rightness with God's word as revealed by the host preacher. These rewards are shown in Table 5.

\section{DISCUSSION}

This section will elaborate on the interrelationship of the results presented above. It will then identify strengths and weaknesses of the study.

Podcasts offer religious entities a means of making a more personal connection with faithful listeners than through the use of traditional radio and television programming. Podcast listeners are in charge of the communication from the outset. Listeners can decide what programs to download and when to listen.

While this study involved a small number of ministries and podcasts, it nevertheless demonstrated that ministries were unable to make podcasts consistently available to listeners during the study period. The faithful listener who might hope to hear a new podcast every day (as one would expect with other forms of podcast programming) would have been disappointed by each of the five ministries.

In addition to making a personal connection with listeners, one would also expect podcasts, like any form of audio/visual programming, to offer audience 
TABLE 5

Explicit or Implied Promise of Rewards Promised to Faithful Listeners

\begin{tabular}{|c|c|c|c|c|c|c|}
\hline & $\begin{array}{c}\text { Copeland } \\
(n=24)\end{array}$ & $\begin{array}{l}\text { Dollar } \\
(n=14)\end{array}$ & $\begin{array}{l}\text { Houston } \\
(n=2)\end{array}$ & $\begin{array}{l}\text { Meyer } \\
(n=21)\end{array}$ & $\begin{array}{c}\text { Osteen } \\
(n=6)\end{array}$ & $\begin{array}{c}\text { All } \\
(n=67)\end{array}$ \\
\hline Lifestyle improvement & 0.42 & 0.57 & 1.00 & 0.86 & 0.83 & 0.74 \\
\hline $\begin{array}{l}\text { Emotional satisfaction; peace } \\
\text { of mind }\end{array}$ & 0.21 & 0.43 & 1.00 & 0.67 & 0.50 & 0.56 \\
\hline Blessings of God & 0.38 & 0.64 & 0.50 & 0.10 & 0.83 & 0.49 \\
\hline $\begin{array}{l}\text { Rightness with God's revealed } \\
\text { word }\end{array}$ & 0.29 & 0.64 & 0.50 & 0.14 & 0.50 & 0.42 \\
\hline Rightness with God & 0.17 & 0.50 & 0.00 & 0.24 & 0.50 & 0.28 \\
\hline Economic gain & 0.13 & 0.29 & 0.00 & 0.14 & 0.00 & 0.11 \\
\hline Health and wellbeing & 0.33 & 0.00 & 0.00 & 0.00 & 0.00 & 0.07 \\
\hline Freedom from the Devil & 0.17 & 0.07 & 0.00 & 0.05 & 0.00 & 0.06 \\
\hline $\begin{array}{l}\text { Civil or human rights, } \\
\text { acceptance or related } \\
\text { satisfaction }\end{array}$ & 0.13 & 0.07 & 0.00 & 0.10 & 0.00 & 0.06 \\
\hline $\begin{array}{l}\text { Political rights, acceptance or } \\
\text { related satisfaction }\end{array}$ & 0.22 & 0.00 & 0.00 & 0.00 & 0.00 & 0.04 \\
\hline $\begin{array}{l}\text { Rightness with God's word as } \\
\text { revealed by this preacher }\end{array}$ & 0.04 & 0.00 & 0.00 & 0.00 & 0.17 & 0.04 \\
\hline
\end{tabular}

(Multiple rewards were promised within individual episodes).

Tables represent rate of occurrence of rewards promised within podcast episodes.

members content that is informative and entertaining. While it is beyond the scope of this research to make a judgment on podcasts' information and entertainment value, an objective judgment can be made on the presentation and structure of programming.

The podcasts analyzed for this study were formulaic. The majority of episodes in each ministry's series were structured the same way, with the same elements, in the same order. There was little that would surprise a returning listener. This observed lack of spontaneity seems antithetic to the concept of podcasting as a new medium that is edgy and different from the traditional media it supplants.

The religious claims made within the podcasts were consistent with renewalist evangelicals" "health and wealth" philosophies. At the same time, some listeners might find that the general formulaic nature of the podcasts themselves, together with an almost complete focus of delivering religious themes through preaching, does not allow a complete portrait of all that the Christian experience has to offer. Christian music "is a strong and gentle companion in bringing vitality to the church, and to the world," one pastor has observed (Hardy, 2005, para. 1). In these renewalist podcasts, music exists only as a brief instrumental bridge between program elements. It was not an evangelistic tool. 
Most ministries spent most of their podcast time directing persuasive communication toward already committed listeners. Although podcasts did offer what was known as a "come to Jesus" opportunity for followers to pray and dedicate their lives to Christ, this opportunity was available in only $9 \%$ of podcasts analyzed. It always followed program content directed toward the already committed. Thus, it was easy to get the impression that, at least within this small sample, program creators were more concerned with continuing a relationship with already committed followers than trying to open a dialogue with first-time listeners searching for religious comfort.

Each of the preachers featured in the podcasts stayed true to key themes of renewalist Christian theology. Within this context, each preacher had a distinct style and framed his/her message to target a specific type of listener. The podcast format is well-suited for this, because of its potential for a personal relationship with the listener.

Each preacher offered a wealth of support for the committed listener, at least on the surface level. There were Bible references, personal anecdotes, preachers' personal stories of faith, and opportunities for listeners to pray along with the preacher. At the same time, just $7 \%$ of the podcasts identified Bible reading or study as an important response of listeners. An even smaller percentage identified church attendance as important $(6 \%)$ or featured testimony from lay believers $(3 \%)$. None of the podcasts asked listeners to volunteer their services to the ministry. The lack of encouragement for listeners to be involved in scriptural study, church attendance, or volunteerism would seem to deny the importance of what's needed on a personal level for a follower's faith to take root.

Fundraising and merchandising communication was evident throughout podcast programming. Unlike traditional Christian radio and TV programming, there was no break between the preaching and the product sales. Preachers would segue effortlessly from a persuasive argument about right living to a sales pitch for their latest book or DVD that listeners should purchase to help them live right. Preachers defended the practice on occasion. The most heavily invested in merchandising was Joyce Meyer, who argued (June 13) that ". . . anybody who tries to teach anybody anything always offers them information on tape." This is consistent with long-standing televangelist philosophy (Smith, 2000; Eskridge \& Knoll, 2000).

The amount of time dedicated to fundraising and product sales in most of the podcasts in this study was proportionately higher than what Winzenburg found in his study of religious TV programs (2001). Winzenburg's research showed TV ministries spent an average of seven minutes an hour on fundraising and marketing, or about $11 \%$ of total time. While the sampling of content from the podcast universe is much smaller than the 150 broadcasts Winzenburg analyzed, the three most active merchandisers identified in this study (Meyer, 
Dollar, and Copeland) dedicated $17 \%, 16 \%$, and $15 \%$, respectively. The small sampling of Osteen and Houston podcasts does not allow them to be effectively compared in this respect.

\section{CONCLUSION}

This study involved a small sampling of renewalist evangelical Christian ministries and a small number of the podcasts they made available during a limited time frame. It would be unwise to attempt many generalizations about what Christian ministries as a whole are doing with podcasts, or what Christian podcast listeners in general are listening to. Still, the results can offer a small glimpse of what a few high-profile ministries in one segment of the Christian world were doing - and not doing - with digital audio during the study period.

Christian podcasts have potential to offer a highly personalized audio experience that would encourage listeners to strengthen their faith, act righteously, and help others. However, the podcasts analyzed in this research were found to be almost completely devoid of support for Bible study, church attendance, and volunteer activity. As a result, listeners could have been led to think those activities are immaterial to the development of Christian faith and conduct. Further research is needed to determine how other podcast programming in the Christian genre deals with this issue, and how listeners react.

Through their inherent interactivity, Christian podcasts have the potential to open a relationship between listeners and ministries. The podcasts analyzed in this research offered little opportunity for a relationship other than through financial donation or product purchase. As a result, listeners could have been led to think that "health and wealth" offered by renewalist ministries comes, literally, through buying into what ministries have to offer. Further research is needed to determine the extent to which other Christian organizations use podcasting to facilitate financial transactions - and the extent to which faithful listeners are compliant.

The podcasts analyzed in this study promised listeners that their faith would be rewarded through lifestyle improvement, emotional satisfaction, and receipt of God's blessings. Given the observed redundancy in program structure and content, one has to wonder if, over the long term, listeners would be sufficiently challenged to continue listening in hope of hearing something new and different. A research effort targeting listeners would allow us to learn more about how they report being influenced by programming.

A key question that is beyond the scope of this research and remains unanswered is the extent to which podcast programming is a supplement to, or a substitute for, church attendance. Aside from the availability and portability of the messages themselves, there did not seem to be content within the podcasts 
that was obviously superior to what listeners could experience through church attendance. In fact, one could argue that the somewhat clumsy editing of sermons into podcast-sized chunks as already noted has the potential to take away much of the potential significance of those sermons. But audience members may not feel this way. In their article that focused on the uses and effects of religious television, Korpi and Kyong (1986) concluded that people often perceived religious TV programming as a favorable substitute for church attendance. Therefore, further research would be warranted to identify regular listeners of Christian podcasts and find out how podcast listening influences decisions about church attendance.

It would also be helpful to engage a research effort that focuses on the processes at work inside the religious organizations that are creating podcasts. Without knowledge of what these ministries hope to obtain and the development that goes on behind the scenes, judgments about the quality of the product seem somewhat irrelevant. In short, we need to know more about the "who," "how," and "why" of podcast production before we can make claims about the "what" (the product) that results from the process.

Perhaps a final overriding question is whether the development of online media such as podcasts is simply further evidence of the advance of consumerism into Christianity and the fragmenting of the body of believers. Much more investigation is needed before we can address this question with certainty.

\section{REFERENCES}

Babbie, E. R. (1990). Survey research methods (2nd ed.). Belmont, CA: Wadsworth.

Bannan, K. J. (2006). Using podcasts to build brands. BtoB Magazine Online. Retrieved February 21, 2007, from www.btobonline.com/apps/pbcs.dll/article?AID=20060403/FREE/604030707\&template $=$ printart

Biema, D. V., \& Chu, J. (2006, September 18). Does God want you to be rich? Time, 48-56. Retrieved June 1, 2007, from Ebscohost database

Blake, J. (2007, January 29). Study finds growing churches embrace diversity and music. San Luis Obispo, CA, Tribune, p. A5.

Bluem, A. W. (1969). Religious television programs: A study of relevance. New York: Hastings House.

Brown, D. (2006, August). Generation iPod: An exploratory study of podcasting's "innovators." Paper presented at the annual meeting of the Association for Education in Journalism and Mass Communication, San Francisco.

Bullis, K. (2005, October). Podcasting takes off. Technology Review, 30.

Church for Men E-newsletter. (2005, November 15). Chugiak, Alaska: Church for Men. Retrieved June 29, 2007, from http://www.churchformen.com/eNewsletter\%20archives/15November05.html

Cutbirth, C. W. (1983, May). The ethics of media framing of issues of the 1980 presidential campaign. Paper presented at the annual meeting of the International Communication Association, Dallas, TX. (ERIC document ED 233412)

Entman, R. M. (1983). Framing: Toward clarification of a fractured paradigm. Journal of Communication, 43, 51-58. 
Eskridge, L., \& Noll, M. A. (Eds.). (2000). More money, more ministry: Money and evangelicals in recent North American history. Grand Rapids, MI: William B. Eerdmans Publishing.

Hadden, J. K. (1987). Religious broadcasting and the mobilization of the New Christian Right. Journal for the Scientific Study of Religion, 26(1), 1-24.

Hadden, J. K., \& Shupe, A. (1987). Televangelism in America. Social Compass, 34(1), 61-75.

Hardy, D. W. (2005, April 3). Music in the life of the church. Retrieved June 18, 2008, from http:// www.ely.anglican.org/parishes/camgsm/sermons/S2005e/dh1.html

Herrington, J. D. (2005). Podcasting hacks. Sebastopol, CA: O’Reilly Media.

Himmelstein, H. (1984). Television myth and the American mind. New York: Praeger.

Howley, K. (2001). Prey TV: Televangelism and interpellation. Journal of Film and Video, 53(2), $23-27$.

Humphries, S. (2004, December 10). "Podcast" your world. The Christian Science Monitor, 12.

Huntsberger, M., \& Stavitsky, A. (2007). The new "podagogy": Incorporating podcasting into journalism education. Journalism \& Mass Communication Educator, 61(4), 397-410.

Inglis, A., Ling, P., \& Jootsen, V. (2001). Delivering digitally: Managing the transition to the knowledge media (2nd ed.). London: Kogan Page.

Johnson, L., \& Grayden, S. (2006). Podcasts — an emerging form of digital publishing. Journal of Computerized Dentistry, 9(3), 205-218.

Karkabi, B. (2006, February 11). Personalizing "truth" makes it less divisive: Radio host believes those who differ on religious issues can have a dialogue. Houston Chronicle, p. 1.

Kennedy, H. (2005, December 25). Thank pod, a sermon you can download. New York Daily News, p. 15.

Klaassen, A. (2006, August 31). Reality check: Blogs and ipods are potent tools, but the reach most marketers crave still comes from good ol' TV, print and Internet ads. Advertising Age, p. 1.

Kloer, P. (2006, November 4). Nuns reach out with "Godcasts." Atlanta Journal-Constitution, p. 4.

Korpi, M. F., \& Kyong, L. K. (1986). The uses and effects of televangelism: A factoral model of support and contribution. Journal for the Scientific Study of Religion, 25(4), 410-423.

Lesig, L. (2001). The future of ideas: The fate of the commons in a connected world. New York: Random House.

Marsal, K. (2006, May 24). iPod: How big can it get? AppleInsider. Retrieved July 17, 2007, from http://www.appleinsider.com/article.php?id=1770

Olsen, T. (2006, December 5). What really unites Pentecostals? Christianity Today, 18-19. Retrieved May 28, 2007, from Ebscohost database

100 million iPods sold. (2007, April 9). Apple Corporation. News release. Retrieved July 17, 2007, from http://www.apple.com/pr/library/2007/04/09ipod.html

Papacharissi, Z. (2002). The presentation of self in virtual life: Characteristics of personal home pages. Journalism \& Mass Communication Quarterly, 79(3), 643-660.

Papacharissi, Z., \& Rubin, A. M. (2000). Predictors of Internet use. Journal of Broadcasting and Electronic Media, 44(2), 175-196.

Patten, J. (2006, February/March). Exploring new ways to communicate. Computers and the Law, 17.

Potter, D. (2006, February/March). iPod, you pod, we all pod: Eager to lure news consumers, media outlets are experimenting with news-on-demand podcasts. American Journalism Review, 64.

Ralli, T. (2005, August 30). Religion on demand iPod helps the busy faithful catch up. International Herald Tribune, 15.

Richardson, W. (2006). Blogs, wikis, podcasts, and other powerful tools for classrooms. Thousand Oaks, CA: Corwin Press.

Smith, G. S. (2000). Evangelicals confront corporate capitalism: Advertising, consumerism, stewardship, and spirituality, 1880-1930. In L. Eskridge \& M. A. Noll (Eds.), More money, more ministry: Money and evangelicals in recent North American history (pp. 39-80). Grand Rapids, MI: William B. Eerdmans Publishing.

Snodgrass, M. (2007). Researching podcasts: Here's how to do it.PR News Digital PR Report. Retrieved May 16, 2007, from http://prnewsonline.com/digitalpr/howto/researching_podcasts.html 
Spirit and power: A 10-country survey of Pentecostals (2006, October). Washington, DC: Pew Forum on Religion and Public Life. Retrieved June 1, 2007, from pewforum.org/surveys/pentecostal

Symonds, W. C., Grow, B., \& Cady, J. (2005, May 23). Earthly empires. Business Week, pp. 78-88. Retrieved May 29, 2007, from Ebscohost database

Tankard, J. W. (1997, July 30-August 2). PR goes to war: The effects of public relations campaigns on media framing of the Kuwaiti and Bosnian crises. Paper presented to the annual meeting of the Association for Education in Journalism and Mass Communication, Baltimore, MD.

Timiraos, N. (2006, July 12). Pastor's sermons to test viability of paid podcasts. Wall Street Journal (Eastern Edition), p. B2.

Winzenburg, S. (2001, October 22). Televangelist report card. Christianity Today, pp. 88-91. 